\title{
Fluktuacje cenowe surowców pochodzenia rolniczego na przykładzie ziemniaków i ich wpływ na przemysł przetwórczy
}

Marcin Kuczyński*

\section{Wstęp}

Jednym z najważniejszych wyzwań dla przemysłu przetwórczego opartego na produktach pochodzenia rolniczego jest zapewnienie stabilności cenowej i jakościowej materiałów do produkcji. Niniejszy artykuł postara się przybliżyć problemy związane z agrobiznesem i jego wpływem na zakłady produkcyjne przetwórstwa spożywczego. Agrobiznes już od dawna oznacza sumę wszystkich operacji związanych z zaopatrzeniem, magazynowaniem oraz przemysłem przetwórczym opartym na produktach rolnych (Davis, Goldberg 1957, s. 1). Niestety z surowcami pochodzenia rolniczego związane są bardzo duże wahania, jeśli chodzi zarówno o jakość, jak i ich dostępność, a co za tym idzie - cenę. Dodatkową wadą surowców pochodzenia rolniczego jest trudność ich wymiany. Czas potrzebny na zastąpienie brakującego lub niezgodnego ze specyfikacją surowca to zazwyczaj rok - tyle trwa sezon rolniczy (uzależniony od pór roku i pogody). Dlatego jednym z najważniejszych problemów poruszanych zarówno przez korporacje, jak i rządy państw jest bezpieczeństwo dostaw żywności, zapewnienie ciągłej dostępności podstawowych produktów żywnościowych dla utrzymania stabilnej ekspansji konsumpcji żywności oraz offsetowania fluktuacji w produkcji i cenach (UN 1974). W związku z tym w zaopatrzeniu zakładów produkcji żywności coraz większą rolę odgrywają procesy kontraktacji oraz integracji pionowej, co powoduje narzucanie standardów postępowań przez producentów (Szymanowski 2008). Inni autorzy również zauważają, że łączenie rynków krajowych ze światowymi, które miałyby miejsce w systemie wolnego handlu nieposiadającego zapasów rządowych, mogłoby zmniejszyć zmienność światowej ceny zbóż o jedną trzecią. Należy też zwrócić uwagę na to, że każda analiza niestabilności żywności

\footnotetext{
* Marcin Kuczyński - magister inżynier, Uniwersytet Ekonomiczny we Wrocławiu, Wydział Nauk Ekonomicznych, Katedra Międzynarodowych Stosunków Gospodarczych, mkuczynski@lbsnacks.pl.
} 
musi odróżnić niestabilność z powodu wahań produkcji krajowej od niestabilności kosztów importu jednostkowego i np. cen światowych. (Vanzetti 1998) Oczywiste jest, że poza kosztami uprawy roślin rolniczych jednym z najważniejszych czynników wpływających na końcową cenę jest plon osiągany z hektara. To, jak znaczącym wahaniom podlega plon, obrazuje rysunek 1. Szczególnie widoczne jest to w przypadku krajów bałtyckich.

Rysunek 1. Zmiany w plonowaniu. Okres transformacji ekonomicznej. Pierwsza dekada transformacji (indeks)

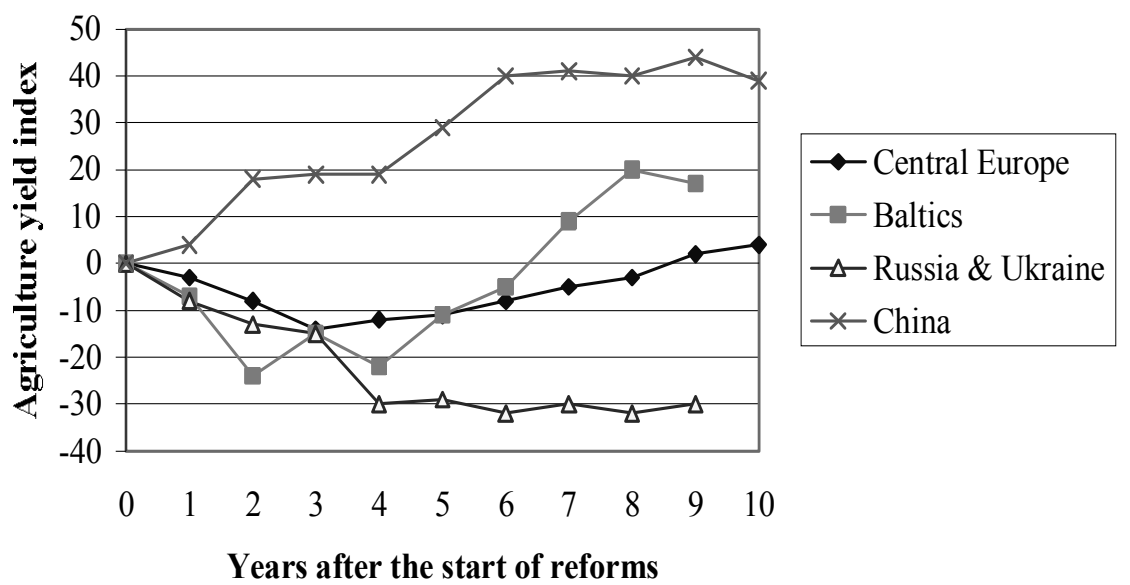

Źródło: FAO 2003, s. 224.

Globalizacja pozwoliła produkcji rolnej znacznie szybciej się rozwijać (Mellor 1992), jednak wyśrubowane oczekiwania dotyczące plonów niosą ze sobą dodatkowe zagrożenie - związane z możliwością ich nieuzyskania podczas niekorzystnej pogody. W konsekwencji może zabraknąć surowców dla zakładów przetwórczych. W przypadku surowców pochodzenia rolniczego czas związany z wyprodukowaniem surowca zastępczego jest bardzo długi. Dlatego w przypadku popytu przekraczającego podaż natychmiast występuje drastyczny wzrost ceny. Taka sytuacja sprzyja nielojalnym zachowaniom, które dodatkowo zwiększają niedobór dostaw, oraz prowadzi do uruchomienia importu, przy czym różnica w cenie jest tak duża, że wysokie koszty i ryzyko związane z transportem przestają mieć znaczenie. Dlatego, by zapobiec wahaniom cen, stosuje się zapasy bezpieczeństwa. Według FAO konieczny do zapewnienia światowego bezpieczeństwa żywności minimalny poziom światowych rezerw zbóż to $17-18 \%$ spożycia (FAO 1999).

Celem artykułu jest przeanalizowanie literatury i ocenienie możliwych przyczyn fluktuacji cen i dostępności surowców pochodzenia rolniczego oraz dotychczasowych metod zapobiegania takim wahaniom. Artykuł powstał na podstawie 
analizy literatury, obserwacji oraz obserwacji uczestniczących. Istotnym źródłem wiedzy były wywiady z ekspertami odpowiadającymi za zarządzanie łańcuchami dostaw oraz działami zaopatrzenia surowcowego zakładów przemysłu frytkowego i chipsowego w Polsce i Niemczech.

\section{Analiza rynku produktów rolnych i cen na przykładzie ziemniaków}

Jednymi z najbardziej wymagających i obciążonych wahaniami plonowania są rośliny okopowe. Dodatkowym wyzwaniem, jeśli chodzi o zapewnienie bezpieczeństwa dostaw, jest brak możliwości długotrwałego przechowywania (w przeciwieństwie do np. nasion czy zbóż). Pomijając warzywa, których wpływ na przemysł przetwórczy jest niewątpliwie olbrzymi, ale ze względu na różne sposoby zagospodarowania (przemysł i bezpośrednia konsumpcja) trudno jest dokonać jasnego podziału na sprzedaż konsumpcyjną i przemysłową. Dlatego w przypadku upraw wielkoobszarowych analizuje się dane dotyczące buraków cukrowych i ziemniaków przemysłowych. Buraki cukrowe i ziemniaki to jedne z podstawowych dochodowych upraw w rolnictwie wielkoobszarowym. Olbrzymią konkurencją dla buraków cukrowych jest trzcina cukrowa, której uprawa jest tańsza, dlatego uprawa buraków w Europie podlega regulacjom. W związku ze znaczącym wpływem tych upraw na rolnictwo jako całość, a co za tym idzie na gospodarkę, ich rynki są częściowo chronione. Buraki cukrowe są w Europie chronione przepisami, a produkcja cukru jest - a właściwie była - kwotowana. W tym przypadku rywalizacja producentów nie miała większego znaczenia, ponieważ z powodu terminowości rozliczania limitów produkcji cukru możliwe było regulowanie ilości pomiędzy sezonami. W związku z tym ceny buraków cukrowych - pomimo tego, że co roku są negocjowane z plantatorami przez przemysł cukrowniczy - w ciągu roku nie zmieniają się. Obecnie kończy się ochrona polegająca na pełnym nadzorze nad produkcją buraków i cukru. Przemysł cukrowniczy i plantatorzy buraków cukrowych nie wiedzą jeszcze, jakie reguły będą ich dotyczyć.

Zupełnie inaczej wygląda sytuacja na rynku ziemniaczanym. Tutaj wahania, jeśli chodzi zarówno o obsadzane areały, jak i ceny uzyskanego plonu, są bardzo duże. I dzieje się tak pomimo tego, że uprawa ziemniaków przemysłowych wymaga wielu inwestycji. Ziemniaki są uprawiane przez wyspecjalizowane gospodarstwa, ponieważ wymagają specjalistycznego sprzętu, odpowiedniej ziemi oraz doświadczenia i wiedzy. Do maszyn przeznaczonych do uprawy ziemniaków należą m.in. sadzarki i kombajny ziemniaczane. Infrastruktura związana z ich uprawą to systemy nawadniania i przechowalnie. Ziemniaki mogą być zagospodarowywane na wiele sposobów. Na rynku występują ziemniaki konsumpcyjne (zanikające $\mathrm{w}$ związku z rozwojem przemysłu paszowego), ziemniaki paszowe, ziemniaki przemysłowe do produkcji skrobi, granulatów, kostki ziemniaczanej, 
frytek, chipsów, alkoholu. Osobnym działem produkcyjnym są ziemniaki nasienne czyli sadzeniaki, które są materiałem siewnym do dalszych upraw przemysłowych i konsumpcyjnych. Każdy z tych przemysłów oczekuje czego innego, ma inne wymagania jakościowe i preferuje bądź nawet wymaga innych odmian ziemniaka. Ma to znaczący wpływ na dostępność ziemniaków w przypadku poszczególnych produkcji, jak i ich cenę. W analizie zostaną pominięte ziemniaki, co do których wymagania są niższe, więc przemysł przetwórczy może korzystać z ziemniaków przeznaczonych dla innych przemysłów, ponieważ na tamtych rynkach wahania są mniejsze. Również uprawa ziemniaków nasiennych odbywa się na określonych zasadach i pod kontrakty, więc wahania cen zazwyczaj są niższe. Najbardziej wahają się ceny ziemniaków konsumpcyjnych, frytkowych i chipsowych.

Ziemniaki konsumpcyjne to pierwsza duża część rynku. Wymagania co do tych ziemniaków dotyczą głównie wyglądu, kalibrażu i oczywiście smaku, choć na razie rynek europejski dopiero zaczyna zwracać uwagę na odmiany i promować świadomość wśród konsumentów.

Rysunek 2. Wzrost cen ziemniaków konsumpcyjnych w Polsce

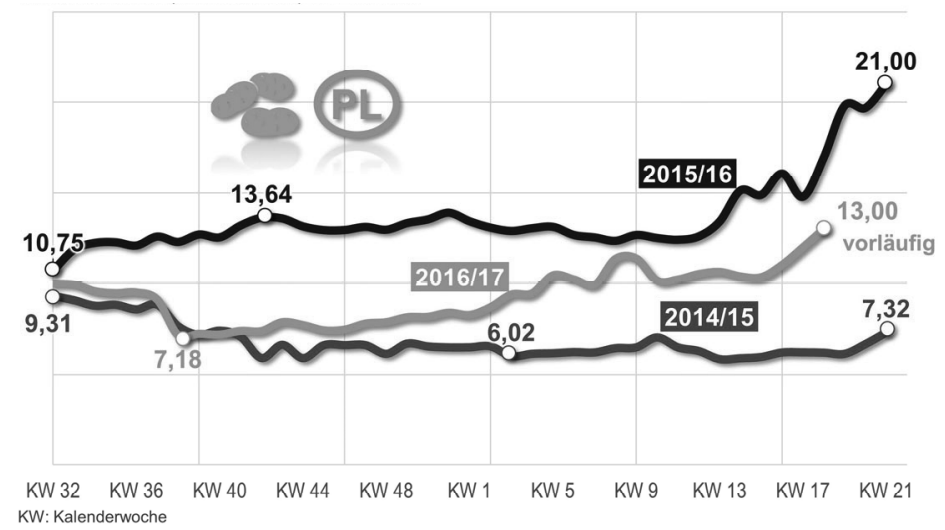

Źródło: AMI 2017.

Rysunek 2 przedstawia wahania cen ziemniaków konsumpcyjnych w trzech ostatnich latach. $\mathrm{Na}$ osi czasu, odzwierciedlającej naturalny sezon wegetacyjny ziemniaków, umieszczone są tygodnie kalendarzowe. Ceny podano w euro za $100 \mathrm{~kg}$. Jak widać, ceny wahały się od 60 do 210 euro za tonę. Nawet w jednym sezonie ceny potrafią wzrosnąć dwukrotnie. W tym przypadku wzrost ceny nie ma jednak tak dużego znaczenia gospodarczego, jak w przypadku ziemniaków przemysłowych, ponieważ klienci kupujący ziemniaki do bezpośredniego spożycia nie zużywają znacznych ilości, a dodatkowo mają alternatywę w postaci kasz, ryżu czy makaronów.

Dużo trudniejsza sytuacja jest na rynku ziemniaków frytkowych i chipsowych. Firmy przetwórcze mają bardzo wysokie wymagania co do jakości i kon- 
kretnych odmian. Ziemniaki jadalne jako mało wymagające jakościowo można zastąpić innymi odmianami, ale w przypadku przemysłu frytkowego i chipsowego dopuszczane do produkcji są tylko odmiany spełniające drastyczne wymagania jakościowe. Jednym z głównych czynników wykluczających użycie ziemniaków stosowanych w innych gałęziach przemysłu jest poziom cukrów redukujących, które sprawiają, że produkt ciemnieje. Jest to spowodowane karmelizacją cukrów prostych podczas procesu smażenia. Najniższy poziom cukrów jest wymagany w przemyśle chipsowym - cukry proste nie mogą przekraczać $0,10-0,12 \%$. Taki poziom jest nienaturalny dla ziemniaków i tylko nieliczne odmiany spełniają ten warunek. $\mathrm{W}$ dodatku w okresie przechowalniczym ziemniaki te wymagają wyższych temperatur, ponieważ nawet ziemniaki odmian chipsowych przechowywane w warunkach charakterystycznych dla ziemniaków innych gałęzi przemysłu, czyli w niższych temperaturach, mają tak wysoki poziom cukrów prostych, że nie nadają się już do produkcji chipsów. Trochę wyższy poziom jest dopuszczalny w przemyśle frytkowym - do około $0,20 \%$. W pozostałych gałęziach przetwórstwa ziemniaczanego, takich jak przemysł skrobiowy, ziemniaków jadalnych, przetworów ziemniaczanych, granulatów oraz przemysł sadzeniakowy, nie ma wymagań dotyczących minimalnego poziomu cukrów prostych, co powoduje, że w ziemniakach tych, nietraktowanych odpowiednio w celu zachowania najniższego możliwego poziomu cukrów po wykopaniu i okresie przechowywania, zawartość cukrów prostych to $0,3-0,5 \%$, co znacząco przekracza poziom cukrów dopuszczalny w przemysłach frytkowym i chipsowym. Różnice w wybarwieniu wysmażonych ziemniaków obrazują rysunki 3-5.

Rysunek 3. Pożądany poziom cukrów redukujących w ziemniakach chipsowych

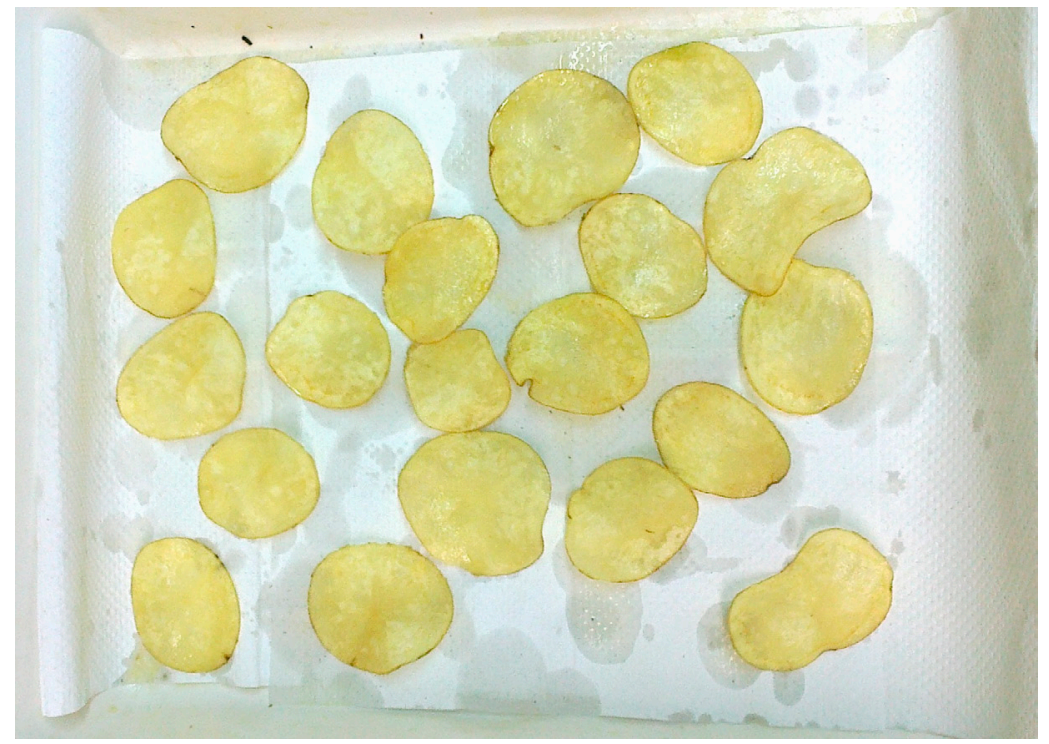

Źródło: opracowanie własne. 
Rysunek 4. Poziom cukrów akceptowany jeszcze w produkcji frytek, ale przekraczający poziom cukrów wymagany w przypadku chipsów

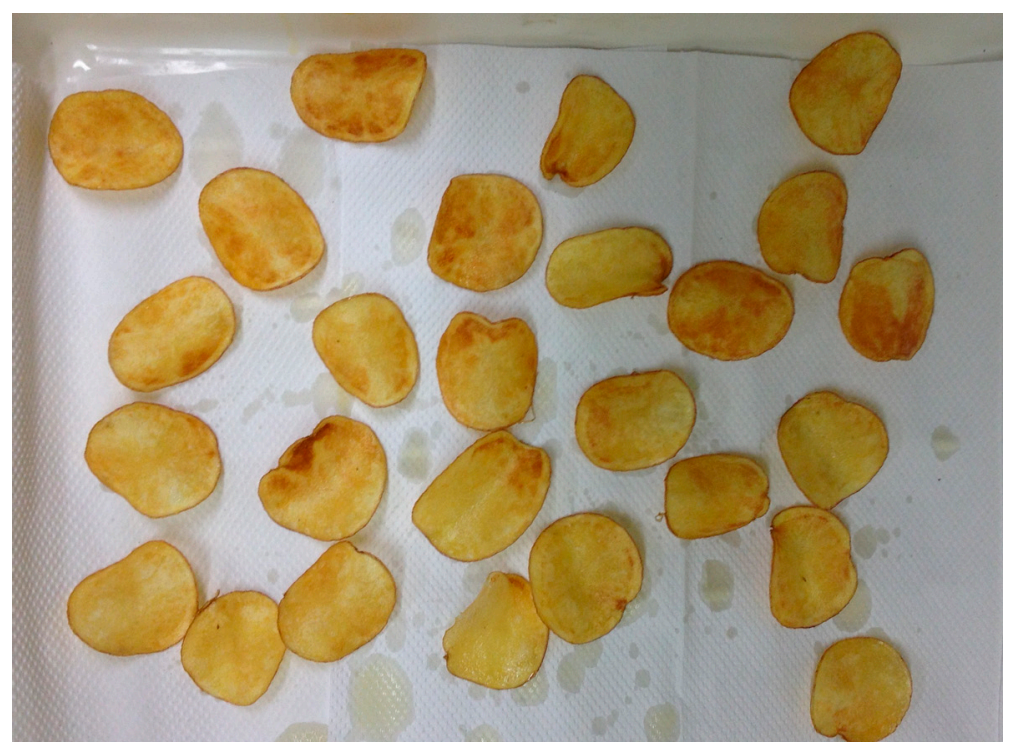

Źródło: opracowanie własne.

Rysunek 5. Poziom cukrów w ziemniakach jadalnych, sadzeniakach i ziemniakach przemysłowych do produkcji skrobi, alkoholu, granulatów

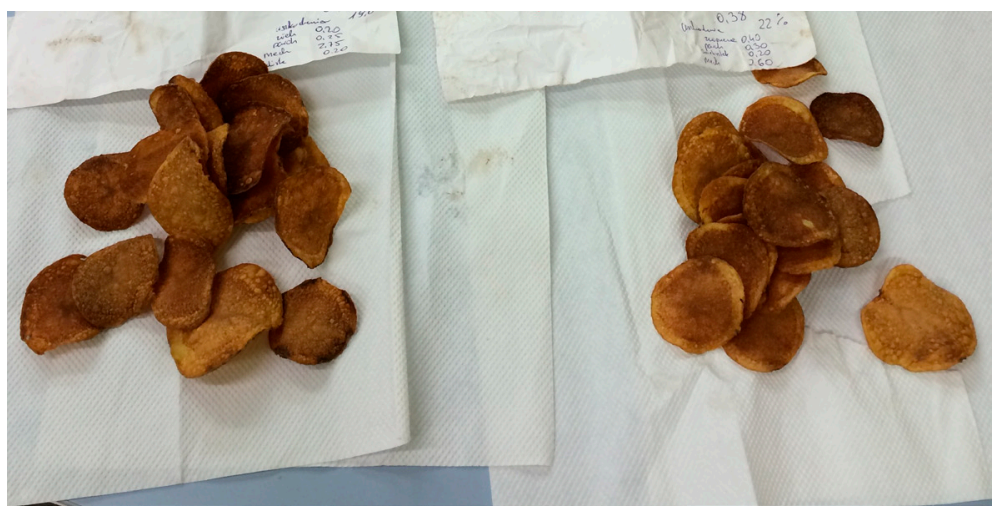

Źródło: opracowanie własne.

W przypadku ziemniaków frytkowych istnieją ogólnodostępne notowania cen. Niektórzy producenci opierają część kontraktów na cenach nawiązujących do cen rynkowych. Jednym z odniesień jest m.in. kurs odmiany Bintje. 
Rysunek 6. Wycena notowań ziemniaków Bintje 2016-2017

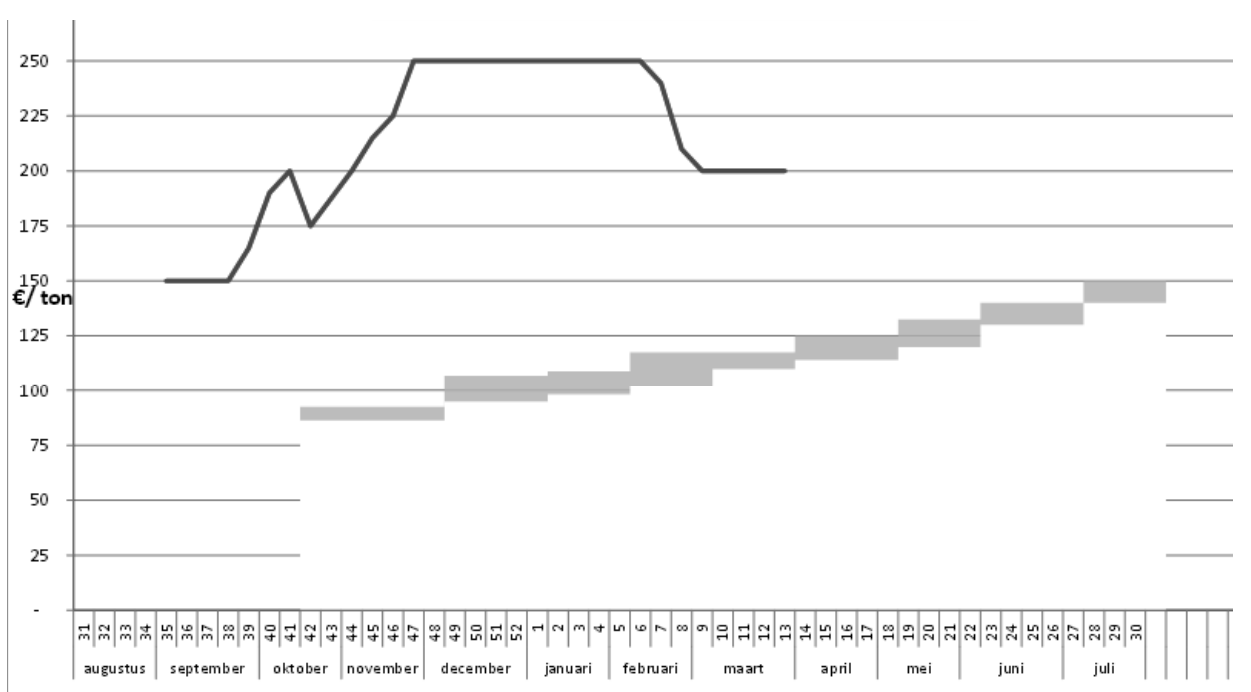

Źródło: Belgapom 2017.

Podana na rysunku 6 wycena ziemniaków Belgapom Bintje jest najczęściej stosowaną ceną notowań poprzedniego dnia dla odmiany Bintje do przetworzenia na mrożone produkty ziemniaczane. Producenci frytek stosują takie notowania, wyceniając część ziemniaków kontraktowo. Pozwala to poniekąd uniknąć braku dostępności ziemniaka, jednak cena pozostaje ceną częściowo rynkową, co ma wpływ na płynność finansową producenta. Jednak płacenie wyższych cen w trudnych latach jest częściowo wyrównywane w latach, w których ziemniaki wolnorynkowe są tanie. Przedstawione na rysunku 6 wykresy obrazują ceny kontraktowe (dolne zakresy). Cienka linia to uśrednione ceny wolnorynkowe. Jak widać, w sezonie 2016-2017 ceny wolnorynkowe okresowo kształtowały się na poziomie $250 \%$ cen kontraktowych i znacznie przekraczały poziom cen ziemniaków konsumpcyjnych (rysunek1). Głównie dotyczyło to ziemniaków frytkowych. W Niemczech różnice cenowe były okresowo jeszcze większe, a w Polsce na Pomorzu plon ziemniaków należał do jednego z najwyższych w historii. Dlaczego więc ziemniaki z Polski nie trafiały na rynek europejski? Spowodowane to jest ograniczeniami w eksporcie ziemniaków z Polski. Eksport ten jest teoretycznie możliwy, ale obostrzenia i kontrole Państwowej Inspekcji Ochrony Roślin i Nasiennictwa praktycznie go uniemożliwiają. Szczególnie dotyczy to ziemniaków chipsowych i frytkowych, których parametry produkcyjne szybko degradują się podczas transportu.

Przemysł chipsowy nie stosuje zapisów w umowach odnoszących się do cen rynkowych z dwóch powodów: po pierwsze, nie ma dostępnych oficjalnych notowań cen ziemniaka chipsowego, a po drugie, olbrzymie wymagania co do jakości 
surowca, pomimo płacenia wysokiej ceny w latach trudnych, nie zapewniają dostępności surowca. W związku z tym wahania cen surowca są jeszcze wyższe - od 420 euro za tonę dla ziemniaków sprowadzanych z Hiszpanii do Polski w lipcu 2012 r., przez 106 euro za tonę ziemniaków z nowego sezonu wegetacyjnego w grudniu tego samego i znów 470 euro za tonę ziemniaków sprowadzanych z Egiptu w 2013 r. W roku 2014 możliwe było kupno pełnowartościowych ziemniaków chipsowych na wolnym rynku poniżej 50 euro za tonę. W ostatnim czasie w Japonii rynek chipsów załamał się z powodu braku podstawowego surowca, czyli ziemniaków (Oda 2017). Cena stugramowej paczki chipsów paprykowych popularnej w Japonii marki Calbee wzrosła z 200 jenów do 1250 jenów. Na Twitterze ukazały się zdjęcia prawie pustych półek. Spowodowane jest to ogłoszeniem przez producenta wstrzymania sprzedaży 15 smaków chipsów z powodu złego plonu ziemniaków w głównym regionie produkcyjnym - Hokkaido. Takich skoków cenowych nie jest w stanie wytrzymać żaden rynek w dłuższym przedziale czasowym. Przy dużej produkcji i podpisanych wieloletnich umowach takie skoki cen są wręcz niemożliwe. Niemożliwe jest również niedostarczenie zamówionego towaru na półkę. Należy zadać pytanie o to, co więc robią firmy przetwórcze, żeby takich sytuacji uniknąć.

\section{Analiza zachowań na rynku}

Tabela 7 przedstawia dane dotyczące dużych zakładów produkcyjnych w Polsce oraz unijnych krajach ościennych. Pomiędzy tymi krajami dochodzi do wymiany zarówno surowców, jak i gotowych produktów.

Tabela 7. Zestawienie producentów frytek i chipsów w Polsce i unijnych krajach ościennych (podane tonaże ziemniaków są szacowane w zaokrągleniu, ponieważ firmy utrzymują je w tajemnicy, podobnie jak tonaż produkowanych wyrobów)

\begin{tabular}{|l|l|l|l|c|}
\hline Kraj & Firma & Produkt & Miejsce & $\begin{array}{c}\text { Tonaż } \\
\text { ziemniaków }\end{array}$ \\
\hline Niemcy & Amberger & Frytki & Oberdolling & 30000 \\
\hline Niemcy & Avico & Frytki & Rain a Lech & 180000 \\
\hline Niemcy & Intersnack & Chipsy & Petersau & 33000 \\
\hline Niemcy & Intersnack & Chipsy & Wevelinghoven & 50000 \\
\hline Niemcy & The Lorenz Bahlsen Snack-World & Chipsy & Neunburg & 60000 \\
\hline Niemcy & The Lorenz Bahlsen Snack-World & Chipsy & Hankensbüttel & 55000 \\
\hline Niemcy & Schne-frost & Frytki & Loeningen & 60000 \\
\hline Niemcy & Stöver/Agrarfrost & Chipsy & Oschersleben & 80000 \\
\hline Niemcy & Stöver/Agrarfrost & Frytki & Wildeschausen & 400000 \\
\hline
\end{tabular}




\begin{tabular}{|c|c|c|c|c|}
\hline Kraj & Firma & Produkt & Miejsce & $\begin{array}{c}\text { Tonaż } \\
\text { ziemniaków }\end{array}$ \\
\hline Niemcy & Wernsing & Frytki & Essen & 200000 \\
\hline Polska & Mc Cain & Frytki & Chociwel & 120000 \\
\hline Polska & Farm frites & Frytki & Lębork & 200000 \\
\hline Polska & Fritar & Frytki & Tarnów & 50000 \\
\hline Polska & The Lorenz Bahlsen Snack-World & Chipsy & Stanowice & 70000 \\
\hline Polska & Intersnack & Chipsy & Nysa & 40000 \\
\hline Polska & Frito Lay & Chipsy & $\begin{array}{l}\text { Grodzisk } \\
\text { Mazowiecki }\end{array}$ & 120000 \\
\hline Polska & FIFOR & Chipsy & Radom & 30000 \\
\hline Czechy & Intersnack & Chipsy & Hradec Kralove & 30000 \\
\hline Węgry & \multirow{2}{*}{$\begin{array}{l}\text { Rynek obsługiwany głównie } \\
\text { przez Intersnack CZ oraz innych } \\
\text { producentów }\end{array}$} & & & \\
\hline Słowacja & & & & \\
\hline
\end{tabular}

Źródło: opracowanie własne.

Osoby odpowiedzialne za zakłady produkcyjne twierdzą, że jednymi z największych problemów w zarządzaniu produkcją są: dostępność, jakość oraz nieprzewidywalna cena surowców pochodzenia rolniczego. Zaburzenia cen i dostępności surowca występują na większości rynków surowcowych, jednak rynek surowców rolniczych charakteryzuje się bardzo długim czasem reakcji. Przykładowo: w przypadku niedoboru ziemniaków po żniwach, czyli zazwyczaj na jesieni, pierwsze ziemniaki uzupełniające ten niedobór mogą się pojawić najwcześniej w lipcu następnego roku. Podobnie jest ze zbożami czy burakami cukrowymi. W przypadku ziemniaków, które powtarzają cechy genetyczne tylko z bulw, a nie nasion, takie zastąpienie jest możliwe tylko pod warunkiem, że dostępne są sadzeniaki do produkcji. Jeśli w związku z niesprzyjającą pogodą brakuje również sadzeniaków, to zastąpienie jest możliwe dopiero za 2-3 lata.

Jak wykazano we wstępie, fluktuacje cenowe występują na rynku ziemniaczanym na całym świecie. Oczywiście takie skoki cenowe są nie do zaakceptowania przez producentów, szczególnie w dobie produkcji prywatnych marek dla sieci. W umowach $\mathrm{z}$ sieciami są określone warunki zakupu i dostawy gotowych produktów wraz z ceną, ilościami i terminem dostarczenia. Biorąc to pod uwagę, niemożliwe jest akceptowanie skoków cen surowca na poziomie $100-300 \%$, bo żaden z producentów nie jest w stanie zrównoważyć takich wydatków oszczędnościami w innych obszarach, a nabywca nie chce płacić wyższych cen. Tym bardziej że nie jest to produkt pierwszej potrzeby, tylko dodatek lub przekąska. Lojalności dostawców nie można sobie zapewnić wysoką ceną, bo nic nie przebije skoków cenowych w roku niedoboru surowca. Poza tym nie tylko cena jest problemem, lecz również brak surowca do produkcji. Co więc robią producenci, 
by związać ze sobą dostawców i zapewnić sobie pełną dostępność surowca nawet w latach, kiedy plony są gorsze? Wspomniane przez Wacława Szymanowskiego budowanie wzajemnego zaufania pomiędzy producentami rolnymi a pośrednikami opiera się na czterech filarach (Readon i in. 2004):

1) scentralizowane zakupy,

2) wyspecjalizowane magazyny i operatorzy przewozowi,

3) dostawcy preferowani,

4) prywatne standardy.

Te cztery filary współpracy pomiędzy dostawcami a producentami są stosowane również $\mathrm{w}$ przetwórstwie ziemniaka, choć nie w równym stopniu przez wszystkie zakłady przetwórcze. Zakupem ziemniaka zajmują się wyspecjalizowane działy agro, które w zależności od zakładu bardziej lub mniej uczestniczą w całym procesie uprawy ziemniaków. Działy te często są zarządzane międzynarodowo i współpracują pomiędzy sobą. Magazyny są wyspecjalizowane, budowane na potrzeby przechowywania ziemniaków, przez niektóre zakłady są też na bieżąco nadzorowane i audytowane przed zasypem. Przewoźnicy muszą być wyspecjalizowani w przewozie ziemniaków oraz posiadać odpowiednie certyfikaty jakościowe, np. Global GAP ${ }^{1}$. Dostawcy stanowią stałą grupę i są corocznie oceniani pod względem np. potencjału, osiąganych wyników i jakości. Firmy przetwórcze tworzą też własne standardy, choć spełniają skomplikowane standardy jakościowe, np. BRC i IFS. Zakłady produkcyjne stosują też inne zabiegi:

1) Pokrywanie kontraktacją co najmniej $100 \%$ planowanych potrzeb. W umowach są zapisy zachęcające wykonanie kontraktacji: premie za wykonanie $100 \%$ kontraktu, premie lojalnościowe wypłacane w roku następnym zależne od ilości dostarczonego surowca, kary za niewykonanie kontraktacji. Czemu same kary nie wystarczą? Ponieważ rolnictwo jest obarczone wpływem pogody niezależnym od rolnika i zawsze może się on takim wpływem obronić.

2) Stały nadzór nad uprawą i doradztwo. Pracownicy działów agro przetwórców ziemniaka na co dzień nadzorują uprawę. Kontrolują pola dostawców i ziemniaki w przechowalniach. Pełnią funkcje doradców, mają wiedzę o plonach, zarówno tych na polu, jak i w przechowalniach, oraz o jakości zapasów surowca.

3) Budowanie wieloletnich relacji z plantatorami. Opieranie się na stałej grupie dostawców, których nie zmienia się nawet wtedy, kiedy znajdują się chętni którzy czasowo mogliby oferować niższe ceny. Umowy są zawierane często na wiele lat, co zapewnia stabilność zarówno zakładom, jak i dostawcom.

4) Różne programy inwestycyjne - zarówno w maszyny uprawowe czy żniwne, jak i systemy nawadniania ziemniaków. Zakłady przetwórcze często współfinansują takie zakupy albo są gwarantami w procesach za-

\footnotetext{
${ }^{1}$ Global G.A.P. - Good Agriculture Practice - Dobrowolny standard jakościowy w rolnictwie promowany przez niektóre sieci handlowe.
} 
kupowych kredytowania lub leasingu. $Z$ jednej strony zapewnia to lepszą jakość surowca, a z drugiej buduje relacje i powiązania pomiędzy producentem a przetwórcą.

5) Dostawa najdroższego materiału do produkcji, jakim są sadzeniaki, i jego finansowanie.

6) Całkowicie niefinansowe wartości oferowane dostawcom: stabilność, pewność odbioru. Brzmi to naturalnie, jednak na rynku skupu płodów rolnych wcale nie jest to powszechne zjawisko. Każdy z polskich rolników doświadczył nieuczciwości ze strony podmiotów skupowych, które również próbują wykorzystać niestabilność rynku i cen.

Ta ostatnia strategia wynika z pozycji dostawcy. Można wtedy do problemu podejść od strony marketingowej. Informacja dla klienta (dostawcy), propozycja oferowanej wartości powinna zostać przedstawiona w formie zysku międzyorganizacyjnego, a nie w jednostce monetarnej, co może dostarczyć wielu użytecznych wartości w interaktywnej współpracy pomiędzy potencjalnym dostawcą a przetwórcą (Wouters, Kirchberger 2015), np. dwustronna lojalność. Wzorując się na zakupach rządowych, preferujących towary krajowe nawet wtedy, gdy są droższe lub gorszej jakości od zagranicznych (Pawlak, Poczta 2011), zakłady starają się chronić swoich dostawców, kiedy mają problemy np. jakościowe, licząc na zwrot w postaci lojalności w latach trudnych dla przetwórcy.

\section{Wnioski}

Agrobiznes, podobnie jak inne sektory, jest wymianą towarów i pieniędzy. Firmy tradycyjnie oparte na przetwarzaniu zatrudniają specjalistów pośredniczących w umowach z producentami oraz w różnych innych sprawach dotyczących współpracy. Dominacja kilku firm na wielu rynkach oczywiście wpływa na ekonomikę sektora (FAO 2003, s. 124).

Problemem, który autor osobiście odczuł podczas przejmowania odpowiedzialności za działy zapewnienia surowca rolniczego dla fabryk przetwórczych, był brak opracowań dotyczących tego, jak zapewnić sobie taką lojalność rolników. Tezę tę potwierdzono w rozmowach z przedstawicielami takich zakładów ziemniaczanego przemysłu przetwórczego jak The Lorenz Bahlsen Snack-World, McCain, Intersnack, Farm Frites w Polsce i w Niemczech. Do dziś zakłady przetwórcze tworzą systemy zacieśniania współpracy z dostawcami, jednak poruszają się po omacku, bazując na doświadczeniu własnych pracowników. Konieczne jest więc przeprowadzenie wśród producentów rolnych badań, które umożliwiłyby sformułowanie odpowiedzi na pytanie o to, co jest dla nich najważniejsze i jakich zapisów umownych by oczekiwali. 
Autor planuje przeprowadzić takie badania na próbie kilkudziesięciu polskich i niemieckich dostawców ziemniaków chipsowych oraz na szefach spółek produkujących ziemniaki dla zakładów przetwórczych. Powinno to doprowadzić do stworzenia modelu zachowań budującego wieloletnie relacje przetwórców $\mathrm{z}$ dostawcami.

\section{Bibliografia}

AMI (2017), AMI Markt Woche, Kartoffeln, 36/2017, www.ami-informiert.de. Belgaprom (2017), Prijsnotering aardappelen / Cotation pommes de terre bintje; Belgapomprijs / Prix Belgapom 2016-2017, http://belgapom.be/fr/cotationbelgapom (data dostępu: 3.04.2017).

Davis J.H., Goldberg R.A. (1957), A concept of agribusiness, Harvard University, Boston, MA.

FAO (1999), Assessment of the impacts of the Uruguay round on agricultural markets and food security, CCP 99/12 Rev., Rzym.

FAO (2003), Trade reforms and food security: conceptualizing the linkages, www.fao.org/3/a-y4671e.pdf (data dostępu: 20.09.2017).

Mellor J. (1992), Agriculture on the Road to Industrialization, Johns Hopkins University Press, Baltimore, MD.

Oda S. (2017), The Great Japan Potato-Chip Crisis: Panic Buying, \$12 Bags, www.bloomberg.com/news/articles/2017-04-14/the-great-japan-potato-chipcrisis-panic-buying-12-bags (data dostępu: 20.09.2017).

Pawlak K., Poczta W. (2011), Międzynarodowy handel rolny. Teorie, konkurencyjność, scenariusze rozwoju, PWE, Warszawa.

Readon T., Timmer P., Berdeque J. (2004), The rapid rise of supermarkets in developing countries: Induced organizational, institutional \& technological changes in agri-food systems, Electronic Journal of Agricultural and Development Economics, Vol. 1, nr 2.

Szymanowski W. (2008), Zarzadzanie tańcuchami dostaw żywności w Polsce, kierunki zmian, Wydawnictwo Difin, Warszawa.

UN (1975), Report of the World Food Conference, Rome 5-16 November 1974, Nowy Jork.

Vanzetti D. (1998), Global Stocks, Price Stability and Food Security, Statens Jordbrugs- og Fiskeriøkonomiske Institut, Kopenhaga.

Wouters M., Kirchberger M.A. (2015), Customer value propositions as interorganizational management accounting to support customer collaboration, Industrial Marketing Management, Vol. 46. 


\section{Streszczenie}

Artykuł traktuje o wpływie surowców pochodzenia rolniczego, w szczególności ziemniaków, na przemysł przetwórczy oraz o fluktuacjach cenowych i dostępności ziemniaków przemysłowych do produkcji w szczególności frytek i chipsów oraz wpływie tych wahan na przemysł przetwórczy. Celem artykułu jest przeanalizowanie literatury i określenie możliwych przyczyn fluktuacji oraz opisanie dotychczasowych metod zapobiegania im. Autor opisuje możliwe do wprowadzenia rozwiązania budujące wieloletnie relacje producentów z dostawcami surowca, które mogą pomóc zapobiec części największych fluktuacji cen i dostępności ziemniaków lub co najmniej je zniwelować.

Słowa kluczowe: cena ziemniaków, fluktuacje cenowe, surowce pochodzenia rolniczego, frytki, chipsy, produkcja, handel międzynarodowy, agrobiznes

\section{Summary}

Agriculture raw materials' price fluctuations on the example of potatoes and their impact on the food industry

This article deals with the impact of agricultural raw materials, especially potatoes, on the food industry. Unpredictable price changes and raw material availability for the production of chips and French fries influences industry instability. The aim of this paper is to analyse the literature and find possible reasons for the fluctuations and to present current prevention methods. The author suggests it is possible to implement solutions by building long term relationships between farmers and producers. This avoids or minimises price and availability fluctuations of potatoes for the production of chips and French fries.

Keywords: potato price, price fluctuations, agricultural raw materials, French fries, chips, production, international trade, agribusiness

JEL: F18, D24, Q17 